\title{
The effect of profitability, capital structure, and forward-looking information on investment risk
}

\author{
Muhammad Istiqlal JERICO ${ }^{1}$ (D) Wiwik UTAMI ${ }^{2}$ (D)
}

1 Universitas Mercu Buana, Jakarta / INDONESIA, e-mail: mijerico95@gmail.com

2 Universitas Mercu Buana Jakarta / INDONESIA, e-mail: wiwik.utami@mercubuana.ac.id

\section{Abstract}

This study aims to provide empirical evidence of the effect of profitability, capital structure and forward looking information on investment risk. The population used in this research were all banking companies listed in the Indonesia Stock Exchange for the period 2016 to 2018. The sample selection used a random sampling method, and obtained 117 samples. The variables of profitability, capital structure, and forward-looking information refer to the elements of Integrated Reporting (2013) as an independent variable, and investment risk as the dependent variable. Data is collected from bank annual reports and share prices obtained from the website. The analysis method used is multiple linear regression. The results of the study concluded that profitability and capital structure had no effect on investment risk. Forward-looking disclosure has a negative effect on investment risk. This means that forward-looking disclosures can significantly reduce investment risk.

Keywords: Investment Risk, Profitability, Capital Structure, Forward-Looking Disclosure.

Jel Codes: E22, G11, G21, G24

\section{INTRODUCTION}

Investment in the capital market sector is one of the driving forces for the economy in Indonesia. Investors can freely invest their shares in any sector listed on the capital market, be it in the agriculture, mining, market industry, various industries, trade and services, consumption, property, infrastructure, finance, and manufacturing sectors. The banking sector can be considered by investors because the banking sector is one of the sectors on which the country's economy is based. This is because the banking sector is an institution that provides payment mechanisms and instruments for the public. In addition, the banking sector gets a lot of sources of funds collected from the wider community. From this source of funds, then banks process it and use it for business development through credit or loans given to the public. In its implementation, the banking sector is also supervised by the OJK (Financial Services Authority) which is formed by the Government so that the funds that are managed for reporting will be transparent to the wider community, including investors.

Investment activities carried out in the capital market will always be accompanied by various kinds of risks that must be faced by investors. These kinds of risks arise because in general, investment always has 
an element of uncertainty. Investors can only make estimates based on their abilities, both expertise and existing data, to find out how much profit has been made on the investment that has been made, including the degree of deviation from the expected results. Every investor in investing in the capital market must expect a high return with the least possible risk from the funds invested. However, it is contrary to the principle of investment, because if an investor wants a high return, he must be willing to assume a high risk, and vice versa. Therefore, before investing, an investor must first conduct an analysis in order to minimize the risks that will occur and prepare what steps must be taken to overcome these risks.

Banks in Southeast Asia have the potential to lose nearly US $\$ 5$ billion by 2025 due to the growth of nonbank digital payments or financial technology (fintech) which makes payments more instantaneous (financial. bisnis.com, 2019). Such future information reveals that over the next 6 years, banks will face further pressure on card transaction revenues and fees, which in turn creates a large reduction in revenue of 9.6 percent of bank commission income, 3.1 percent of bank revenue, and 1.7 percent of payment income (financial.bisnis. com, 2019). In addition to declining profitability, the banking industry must also be aware of the threat of bad credit, due to an increase in the gross nonperforming loan (NPL) ratio from July 2019 of $2.55 \%$ to $2.60 \%$ in August 2019. The threat of bad credit is the cause of LDR, banking is high, so liquidity will be tighter (harianterbit.com, 2019).

Investing in Indonesia can be a very profitable thing but investing in Indonesia also implies more risks than investing in developed countries because Indonesia has certain dynamics and characteristics that (can) derail investment and disrupt the investment climate. In investing, investors have two decisions, one that sees a certain level of return and a certain risk. Research that examines investment risk is still rare. Therefore, this research will be oriented towards investment risk. This study aims to examine whether profitability, capital structure and future disclosure of information affect investment risk.

\section{LITERATURE AND THEORY}

\subsection{Agency Theory}

Agency relationships occur when the company owner (principal) employs another person (agent) to provide a service and then delegates decision-making authority to that agent (Scott, 2015). In agency theory, a problem known as a conflict of interest arises. Agency relationships in banking companies are more complex when compared to non-bank companies. In banking companies, in addition to an agent-owner relationship, there is also a relationship between agent and debtor and agent and regulator.

\subsection{Signal Theory}

Signaling theory emphasizes the importance of information issued by issuers on investment decisions from parties outside the company. Investors really need accounting information before making an investment, because accounting information can produce a picture of both the past and the future about the development of a company. Information that is complete, relevant, accurate, useful and supports investors in making investment decisions is information needed by investors (Jogiyanto, 2014).

Issuers have accurate information regarding accounting information, so that if the issuer submits accounting information to the capital market, the market will respond to this information as a signal that is reflected in changes in share prices and trading volume. The information submitted can be in the form of company financial reports. Announcement of accounting information provides a signal that the company has good prospects in the future (good news) so that investors are interested in trading stocks, thus the market will react as reflected by changes in the volume of stock trading. Thus, the relationship between the publication of information, be it financial reports, financial conditions, or socio-political to the fluctuations in stock trading volume can be seen in market efficiency.

\subsection{Investment Risk}

Investment risk in the banking sector results from the participation of the bank in bearing the losses of customers' businesses that are financed in profit and loss sharing based profit sharing. This risk arises if the bank provides profit-sharing based financing to the customer and the bank shares the risk for the business loss of the customer being financed (profit and loss sharing). In this case, the calculation of profit sharing is not only based on the amount of revenue or sales that the customer receives but is calculated on the business profit generated by the customer. If the customer's business goes bankrupt, the principal amount of financing provided by the bank to the customer will not be recovered (Prasetyoningrum, 2015). Investors' decision making in investing is based on the expected rate of return, the level of risk, and the relationship between return and risk (Tandelilin, 2010).

\subsubsection{Systematic Risk}

The part of security risk that cannot be eliminated by forming a portfolio is called Systematic Risk (Jogiyanto, 2014). According to Keown (2011), systematic risk is part of the variations in investment returns that cannot be eliminated through diversification by investors. Systematic risk is also called market risk, meaning that risk occurs due to events or events outside the company, such as recession, inflation, interest rates, and exchange rates and so on, so this risk is a risk that 
cannot be diversified.

\subsubsection{Unsystematic Risk}

There is also a risk that can be eliminated by establishing a portfolio or diversifying securities, namely unsystematic risk. The part of security risk that can be eliminated by forming a well-diversified portfolio is called Unsystematic Risk (Jogiyanto 2014). Unsystematic risk is part of the variation in investment returns that can be eliminated through diversification by investors (Keown, 2011). Unsystematic risk is often referred to as company risk unique risk. Unsystematic risk or specific risk only affects a particular stock or sector (Samsul, 2006).

\subsubsection{Total Risk}

The total risk of investment in the capital market is represented by standard deviation. Measuring the total risk of a single investment, namely stocks, can be done by calculating the variance or standard deviation of stock income, which measures the deviation of the income values that have occurred with the expected income. The higher the standard deviation, the higher the risk of investing in a company's stock, on the other hand, a low standard deviation indicates a low risk of investing in stocks. The size of the risk of individual stocks is measured by variance, or standard deviation (Sudana, 2013). The measurement of this total risk can be measured using the following formula (Jogiyanto, 2014):

$$
\sigma=\sqrt{\frac{\sum(R i j-E(R i))^{2}}{n-1}}
$$

\subsection{Profitability}

The profitability of a bank is a comparison of profit after tax with core capital or profit before tax with the total assets owned by the bank in a certain period. In order for the ratio calculation results to be closer to the actual conditions, the position of capital or assets is calculated on average during that period (Abdurahim, Yaya, and Martawireja, 2016). The profitability of a bank can be determined by analyzing its financial statements, which is reflected in the bank's ability to earn profits during a certain period (Nuraini\&Muttaqin, 2018). The main focus in assessing bank performance is the level of a bank's ability to generate profits in its operations because profitability is not only an indicator of the bank's ability to carry out its obligations, but also a reflection of the value creation of a bank that shows its business prospects in the future. The purpose of conducting a profitability analysis of a bank is to measure the level of business efficiency and profitability achieved by the bank concerned.

\subsection{Capital Structure}

The comparison between foreign capital (long and short term debt) and equity (retained earnings and ownership of the company) is referred to as the capital structure. The capital structure has a direct impact on the company's financial position, especially with the debt burden borne by the company. The greater the amount of use of long-term debt compared to own capital, the greater the fixed burden that must be borne by the company in the form of interest expenses. The amount of interest expense borne by the company will reduce the level of profit available to shareholders so that the risk for shareholders will increase (Riyanto, 2010).

\subsection{Forward-looking Information}

Information technology that is developing rapidly has resulted in the increasing diversity of information needs for economic decision making. Decision makers (investors and creditors) have long relied on historical income and cash flow information to predict the future value of companies. In the economic conditions that change rapidly due to the effects of globalization, past performance cannot be used as a predictor of future performance. Decision makers need additional information that can be used to better predict future performance. The main objective of investors and analysts in looking at information that sees the future is to assess future earnings and cash flows (Choi and Meek, 2012). Information that can provide future orientation is forward-looking information.

To face global competition and maintain the trust of its customers, banks are required to be more transparent in disclosing information. The demand for transparency is caused by dissatisfaction with mandatory reporting, which causes investors and other stakeholders to ask for the company to volunteer to disclose more complete information about the company's longterm strategy and performance, and to encourage companies to provide additional disclosures beyond mandatory disclosures.

\subsection{Hypothesis Development}

Investment as one of the right ways to prepare finances in the future because investment can provide a higher level of support compared to the amount invested. In addition, investors must still consider the level of risk borne, because the greater the risk, the greater the expected return. A high level of bank profitability will be followed by a high return so that investment risk will increase.

In addition, investors must also pay attention to the use of the capital structure in the bank. capital structure has a direct impact on the company's financial position, so that the capital structure can affect investment risk because companies that have large debts have a large 
enough risk in front of shareholders, because most of the operating income the bank will be used to finance interest expense.

To mitigate the risk, banking companies further increase voluntary disclosure of future information disclosures that can assist investors in understanding management business strategies, thereby increasing investor interest in investing and reducing information asymmetry. By reducing the level of information asymmetry, financial reports are more transparent and lead to low risk estimation by investors because no information is hidden.

The framework of this research is as follows:

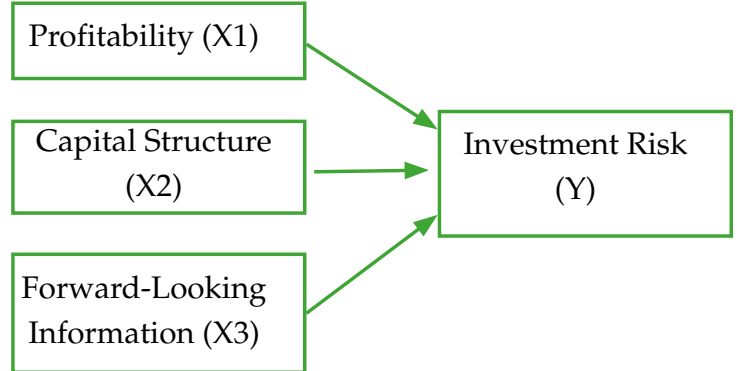

Therefore, the hypotheses in this study are:

H1: Profitability has a negative effect on investment risk

H2: Capital Structure has a positive effect on Investment Risk

H3: Forward-Looking Information has a negative impact on investment Risk

\section{RESEARCH METHOD}

The populations is a banking companies listed on the Indonesia Stock Exchange. Sample were selected for the 2016 until 2018 reporting periods and have complete annual report data for both periods.

The dependent variable in this study is investment risk. This variable is measured by using the standard deviation of income (return) shares of banking companies. The formula are follows (Jogiyanto, 2014):

$$
\sigma=\sqrt{\frac{\sum(R i j-E(R i))^{2}}{n-1}}
$$

Information:

Rij : the rate of profit that occurs in condition $\mathrm{j}$

E (Ri) : the expected rate of profit

$\mathrm{N} \quad$ :observation period

Rij is obtained from stock returns with the closing stock price for 8 weeks in April and May and E (Ri) is obtained from JCI closing for 8 weeks in April and
May. Using April and May closing prices because the annual report must be published within 3 months after the end of the financial year. If the financial year ends in December, financial statements are issued in March. Accordingly, investors will respond to the annual report in April.

The independent variables in this study are profitability, capital structure, and disclosure of future information. Profitability is measured using Return on Assets (ROA). If the Return on Assets in the company is high, then the company has the ability to generate profits so that investors will be more confident that investing in the company will be profitable. The following Return on Assets formula.

$\mathrm{ROA}=\frac{\text { Earning After } \text { Tax }}{\text { Total Assets }} \quad \mathrm{X} 100 \%$

The capital structure in this study is measured by the Debt to Asset Ratio (DAR). The DAR ratio is how much assets are financed by debt or how much the company's debt affects asset management.

DAR $=\frac{\text { Total Debts }}{\text { Total Assets }} \quad \times 100 \%$

Future information disclosure refers to the integrated reporting disclosure perspective. According to IIRC, 2013. Disclosure index is the ratio between the numbers of issuers' disclosures divided by the number of disclosures expected. This expected disclosure has six categories which are divided into 27 disclosure items as presented in Table 1.

Disclosure Index $=\frac{\text { numbers of issuers' disclosures }}{\text { number of disclosures expected }}$

\section{RESULTS AND DISCUSSION}

The study was conducted by taking financial statement data from 117 banking companies listed on the Indonesia Stock Exchange for the period 2016-2018.

Based on Table 3, it can be explained that the results of the analysis of the investment risk variable show an average value of $5.5150 \%$ and a standard deviation of $5,9004 \%$. The profitability variable shows the average value is $0.9038 \%$ and the standard deviation value is $2.4127 \%$. The results of the descriptive statistical analysis of the capital structure variable showed an average value of $76.7225 \%$ and a standard deviation value of $23.8075 \%$. The results of descriptive statistical analysis of the forward-looking information variables showed an average value of $69.26 \%$ and a standard deviation value of $10.721 \%$. 
Table 1. Topics of Disclosure in An Integrated Reporting Perspective Based on IIRC 2013

\begin{tabular}{|c|c|}
\hline Category & Topics of information \\
\hline 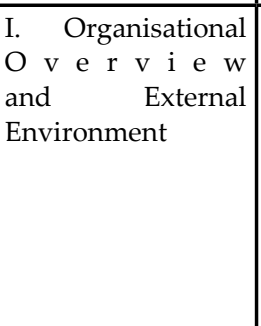 & $\begin{array}{l}\text { 1. The organisation's culture, ethics, and value } \\
\text { 2. The organisation's ownership and operating structure } \\
\text { 3. The organisation's principal activities and market } \\
\text { 4. The organisation's competitive landscape and market positioning } \\
\text { 5. The organisation's position within the value chain } \\
\text { 6. Significant factors affecting the external environment and the organisation's response }\end{array}$ \\
\hline $\begin{array}{l}\text { II. Governance } \\
\text { (GOV) }\end{array}$ & $\begin{array}{l}\text { 7. The organisation's leadership structure including the skills and diversity } \\
\text { 8. Specific processes use to make strategic decisions and to establish and monitor the culture of the } \\
\text { organisation } \\
\text { 9. Particular actions charged with governance to influence and monitor the strategic direction of the } \\
\text { organisation and its approach to risk management } \\
\text { 10. The relationship between culture, ethics, and value with key stakeholders and capital } \\
\text { 11. Remuneration and incentives }\end{array}$ \\
\hline $\begin{array}{l}\text { III. Business } \\
\text { Model (BUS) }\end{array}$ & $\begin{array}{l}\text { 12. Key Inputs } \\
\text { 13. Key business activities } \\
\text { 14. Key Outputs } \\
\text { 15. Key Outcomes }\end{array}$ \\
\hline $\begin{array}{l}\text { IV. Risk and } \\
\text { Opportunities } \\
\text { (RISK) }\end{array}$ & $\begin{array}{l}\text { 16. Specific external source of risk and opportunities } \\
\text { 17. Specific internal source of risk and opportunities } \\
\text { 18. The organisation's assessment of the likelihood that risk or opportunity will come to fruition } \\
\text { 19. The specific steps being taken to mitigate or manage key risks or opportunities }\end{array}$ \\
\hline $\begin{array}{l}\text { V. } \\
\text { Strategy and } \\
\text { Resource (STR) }\end{array}$ & $\begin{array}{l}\text { 20. The organisation's short, medium and long-term strategic objectives } \\
\text { 21. The strategic to achieve strategic objectives } \\
\text { 22. The resource allocation plans to implement the strategy } \\
\text { 23. The linkage between the organisation's strategy and resource allocation plans } \\
\text { 24. What differentiates the organisation to give it a competitive advantage and enable it to create value }\end{array}$ \\
\hline $\begin{array}{l}\text { V. Performance } \\
\text { (PERF) }\end{array}$ & $\begin{array}{l}\text { 25. The organisation's effects on the capitals } \\
\text { 26. The state of key stakeholder relationship and how organisation responds to key stakeholder's } \\
\text { legitimate needs and interests } \\
\text { 27. The linkage between current performance and the organisation's outlook }\end{array}$ \\
\hline
\end{tabular}

Source: Utami and Wahyuni, 2018

The research model used in this study is as follows:

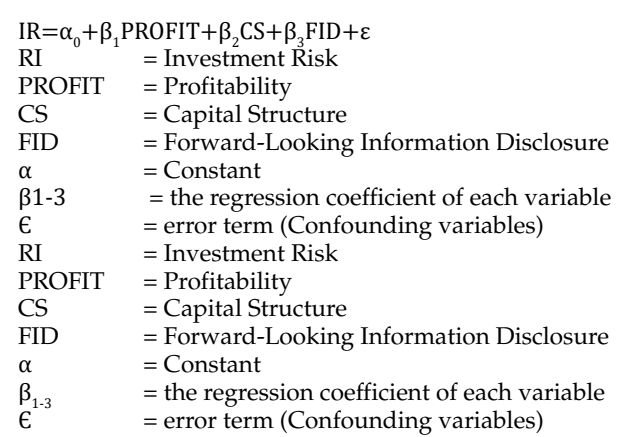


Table 2. Variable Measurement

\begin{tabular}{|l|l|l|}
\hline No & Variable & Measurement \\
\hline 1 & Profitability & ROA $=\frac{\text { Earning After Tax }}{\text { Total Assets }} \times 100 \%$ \\
\hline 2 & Capital Structure & DAR $=\frac{\text { Total Debts }}{\text { Total Assets }} \times 100 \%$ \\
\hline 3 & Forward-Looking Information & Disclosure Index $=\frac{\text { numbers of issuers' disclosures }}{\text { number of disclosures expected }}$ \\
\hline
\end{tabular}

\begin{tabular}{|l|c|c|c|c|c|}
\hline \multicolumn{7}{|c|}{ Table 3. Descriptive Statistics Test Results } \\
\hline & $\mathbf{N}$ & Minimum & Maximum & Mean & Std. Deviation \\
\hline Investment Risk & 117 & $0,87 \%$ & $44,95 \%$ & $5,5150 \%$ & $5,9004 \%$ \\
\hline Profitability & 117 & $-10,77 \%$ & $5,15 \%$ & $0,9038 \%$ & $2,4127 \%$ \\
\hline Capital Structure & 117 & $0,77 \%$ & $96,82 \%$ & $76,7225 \%$ & $23,8075 \%$ \\
\hline $\begin{array}{l}\text { F o r w a r d - L o o king } \\
\text { Information }\end{array}$ & 117 & $33 \%$ & $89 \%$ & $69,26 \%$ & $10,721 \%$ \\
\hline Valid N (listwise) & 117 & & & & \\
\hline
\end{tabular}

\begin{tabular}{|l|l|r|}
\hline \multicolumn{2}{|l|}{ Tource: Output SPSS 25 4. One-Sample Kolmogorov-Smirnov Test } \\
\hline \multicolumn{2}{|l|}{} & Unstandardized Residual \\
\hline $\mathrm{N}$ & Mean & 86 \\
\cline { 2 - 4 } Normal Parameters & Std. Deviation & .0000000 \\
\hline \multirow{2}{*}{ Most Extreme Differences } & Absolute & .34481888 \\
\cline { 2 - 4 } & Positive & .093 \\
\cline { 2 - 4 } & Negative & .093 \\
\hline Test Statistic & & -.048 \\
\hline Asymp. Sig. (2-tailed) & & .093 \\
\hline
\end{tabular}

Source: Output SPSS 25

\begin{tabular}{|l|c|c|c|}
\hline \multicolumn{3}{|c|}{ Table 5. Multicollinearity Test } \\
\hline Variable & Tolerance & VIF & Information \\
\hline Profitability & 0,983 & 1,017 & Not Multicollinearity \\
\hline Capital Structure & 0,995 & 1,005 & Not Multicollinearity \\
\hline $\begin{array}{l}\text { F o r w a r d - L o o k in g } \\
\text { Information }\end{array}$ & 0,989 & 1,011 & Not Multicollinearity \\
\hline Source: Output SPSS 25 & \multicolumn{3}{|}{} \\
\hline
\end{tabular}




\begin{tabular}{|l|c|c|}
\hline \multicolumn{3}{|c|}{ Table 6. Heteroscedasticity Test } \\
\hline Variable & Significance & Information \\
\hline Profitability & .813 & Homoscedasticity \\
\hline Capital Structure & .266 & Homoscedasticity \\
\hline Forward-Looking Information & .066 & Homoscedasticity \\
\hline Source: Output SPSS 25 & \multicolumn{2}{|}{} \\
\hline
\end{tabular}

Graph 1. Heteroscedasticity test with Scatterplot

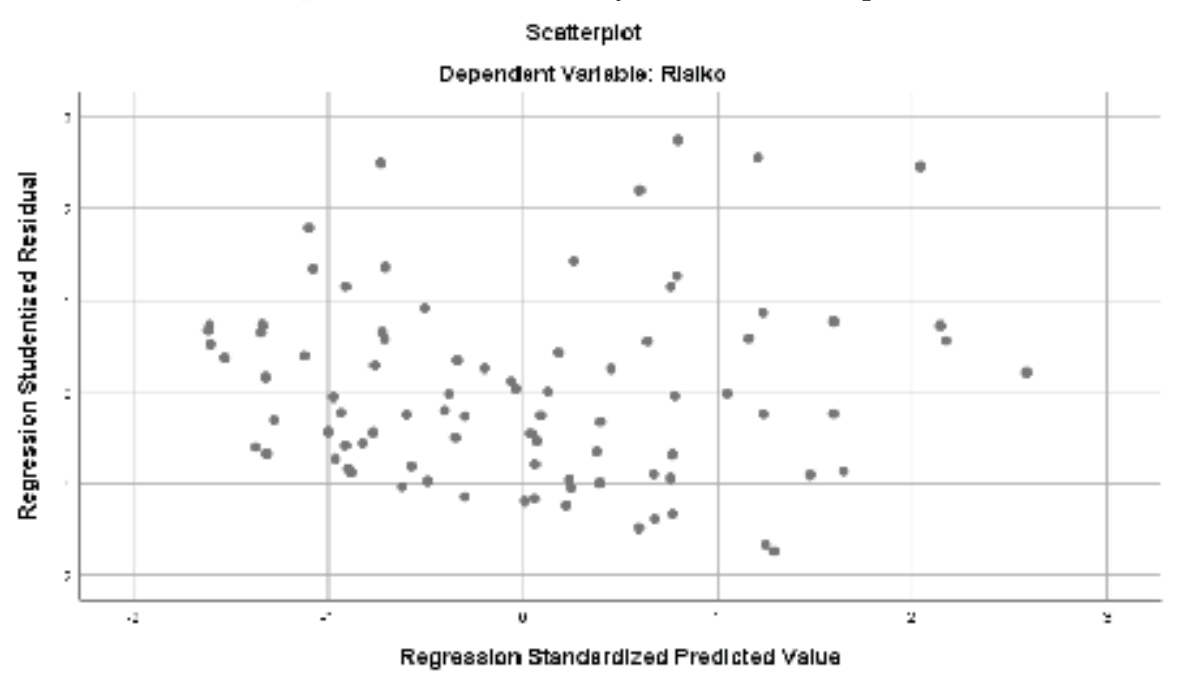

Source: Output SPSS 25

\begin{tabular}{|c|c|c|c|c|c|}
\hline \multicolumn{7}{|c|}{ Tabel 7. Autocorrelation Test } \\
\hline Model & $\mathrm{R}$ & R Square & Adjusted R Square & $\begin{array}{c}\text { Std. Error of the } \\
\text { Estimate }\end{array}$ & Durbin-Watson \\
\hline 1 & $.349 \mathrm{a}$ & .122 & .090 & .35107 & 1.919 \\
\hline \multicolumn{7}{|l|}{} \\
\hline $\begin{array}{l}\text { a. Predictors: (Constant), Forward-Looking Information, Capital Structure, Profitability } \\
\text { b. Dependent Variable: Investment Risk }\end{array}$ \\
\hline Source: Output SPSS 25
\end{tabular}

\begin{tabular}{|c|c|c|c|c|}
\hline \multicolumn{5}{|c|}{ Table 8. Adjusted R Square Test } \\
\hline \multicolumn{5}{|c|}{ Model Summary } \\
\hline Model & $\mathrm{R}$ & R Square & Adjusted R Square & $\begin{array}{c}\text { Std. Error of the } \\
\text { Estimate }\end{array}$ \\
\hline 1 & $.225 \mathrm{a}$ & .051 & .021 & .0302157 \\
\hline a. Predictors: (Constant), Forward-Looking Information, Capital Structure, Profitability \\
\hline
\end{tabular}




\begin{tabular}{|c|c|c|c|c|c|c|}
\hline \multicolumn{7}{|c|}{ Table 9. Statistical Test F } \\
\hline \multirow{2}{*}{ Model } & $\begin{array}{c}\text { Sum of } \\
\text { Squares }\end{array}$ & Df & Mean Square & F & Sig. & \\
\hline \multirow{3}{*}{1} & Regression & 1.402 & 3 & .467 & 3.793 & $.013 b$ \\
\cline { 2 - 7 } & Residual & 10.107 & 82 & .123 & & \\
\cline { 2 - 7 } & Total & 11.509 & 85 & & & \\
\hline
\end{tabular}

\begin{tabular}{|c|c|c|c|c|c|c|}
\hline \multicolumn{7}{|c|}{ Table 10. Statistical T Test } \\
\hline \multicolumn{7}{|c|}{ Coefficientsa } \\
\hline \multirow{2}{*}{\multicolumn{2}{|c|}{ Model }} & \multicolumn{2}{|c|}{ Unstandardized Coefficients } & $\begin{array}{c}\text { Standardized } \\
\text { Coefficients }\end{array}$ & & \\
\hline & & B & Std. Error & Beta & $\mathrm{T}$ & Sig. \\
\hline \multirow[t]{4}{*}{1} & (Constant) & .196 & .214 & & .915 & .363 \\
\hline & Profitability & .015 & .044 & .036 & .348 & .728 \\
\hline & Capital Structure & .033 & .055 & .062 & .596 & .553 \\
\hline & $\begin{array}{l}\text { Forw a rd - L o o king } \\
\text { Information }\end{array}$ & -.911 & .274 & -.346 & -3.320 & .001 \\
\hline \multicolumn{7}{|c|}{ a. Dependent Variable: Investment Risk } \\
\hline \multicolumn{7}{|c|}{ Source: Output SPSS 25} \\
\hline
\end{tabular}

\subsection{Multiple Regression Model Test}

The requirements for multiple regression models to be unbiased are a normally distributed data, autocorrelation, multicollinearity, and heterocedasticity. The result of the regression test assumption was presented in Table 4, Table 5, Table 6, and Graph 1.

Based on Table 4, the test results using one samplekolmogorov-smirnov show that the residual data is normally distributed (the value of Asymp. Sig. (2-tailed) is 0.066 , greater than the significance value of 0.05$)$.

Based on Table 5, it can be seen that the overall tolerance value is above the number 0.10 , and no VIF value is greater than 10 . This shows that there is no multicollinearity for each variable so that regression analysis can be carried out.

Based on Table 6, it can be seen that statistically the significance probability value of all variables exceeds 0.05 so that none of the variables has a significant effect on the absolute residual. So, it can be concluded that the variables in the regression model of this study are free from heteroscedasticity problems because the significance probability value of all variables exceeds 0.05. Meanwhile, in graph 1 the scatterplot shows that all data are randomly scattered around point 0 , so it can be concluded that this does not occur. Heteroskedasticity in the regression model.

Based on table 7 of the autocorrelation test result above, the Durbin-Watson value is 1,919 . This value is greater than the dU value obtained from the DurbinWatson table of 1.7512, and lies between the dU and (4$\mathrm{dU})$ values of $2.2488(1.7512<1.919<2.2488)$. Therefore, these results indicate that the regression model used in this study is free from autocorrelation problems.

Based on table 8, the R Square value shows 0.051. This shows that contribution of the independent variables, namely profitability, capital structure, and forwardlooking information to the dependent variable, namely investment risk, is $5.1 \%$, while the remaining $94.9 \%$ is determined by other variables not examined in this study.

Based on Table 9, the significance value is smaller than the probability value of $0.05(0.013>0.05)$ indicating that the regression model is fit. 
Table 10 above shows the results of the $t$ test. The $t$ test is carried out by looking at the significance column on each independent variable. Table 10 shows the regression coefficient value for each variable, namely profitability of 0.728 which indicates that profitability has no effect on investment risk and $\mathrm{H} 1$ is rejected because the significance value is greater than 0.05 , capital structure is 0.553 which indicates that the capital structure has no effect on investment risk and $\mathrm{H} 2$ is rejected because the significance value is greater than 0.05 , and forward-looking information is 0.001 , thus indicating future information disclosure affects investment risk and $\mathrm{H} 3$ is accepted because the significance value is more smaller than 0.05 .

The profitability of a bank is the comparison of profit after tax with core capital or profit before tax with total assets owned by the bank for a certain period. Profitability is not accurate in predicting its effect on investment risk. The results of this study indicate that profitability has no effect on investment risk, so profitability cannot explain risk. The results of this study are not in line with Isnaini and Ghoniyah (2013), Anggrainy (2015), and Putra and Dana (2016). Has a positive effect on investment risk. The difference in the results of this study may be caused by different years of the study period and the number of company samples, as well as the different measurements used, namely Return on Equity.

The company's capital structure illustrates the comparison between long-term debt and own capital used by the company. Capital structure is not accurate in predicting its effect on investment risk.The results of this study indicate that the capital structure has no effect on investment risk, so the capital structure cannot explain risk. This research is in line with Isnaini and Ghoniyah (2013), Yanti and Rasmini (2014), Abdi and Hidayat (2016), and Astuti (2017) who state that capital structure has no effect on investment risk. However, this research is not in line with Pramana and Badera (2017). The difference in the results of this study may be caused by different years of the study period, the number of company samples and different measurements under study, namely by using the measurement of the Debt to Equity Ratio

Information that can provide future orientation is forward-looking information. Forward-looking disclosure is accurate in predicting its effect on investment risk. The results of this study indicate that disclosure of future information has a negative effect on investment risk. This is presumably because the credibility of banking companies has increased with the existence of bank policies to disclose future information more broadly to assist investors in understanding management business strategies, thereby increasing investor interest in investing and reducing information asymmetry. Research with different perspectives, population and sample size and different research times were also conducted by Mousa and Elamir (2018) showing that the volatility of stock returns has a statistically significant negative relationship to the quantity of disclosures, coverage of disclosures and quality of disclosures. Conversely, the volatility of stock returns has an insignificant relationship with the concentration of disclosure.

\section{CONCLUSION}

Profitability has no effect on investment risk. In the context of this research, investment risk is the total investment risk. This means that profitability is not able to explain the variation in total risk. The same result is also for the solvency ratio which has no effect on the total risk. This finding reflects that profitability and solvency based in theory more strongly reflect fundamental risk than total risk. Disclosure of forward looking has a negative and significant effect on investment risk. The disclosures increased credibility of banking companies with the existence of bank policies to broadly disclose future information to assist investors in understanding management business strategies, thereby increasing investor interest in investing and reducing information asymmetry and investment risk.

\section{REFERENCES}

- ABDURAHIM, A. YAYA, R. \& MARTAWIREJA A. E. (2016). Akuntansi Perbankan Syariah. Jakarta: Salemba Empat.

- ALI, I. (2002). Pelaporan Keuangan dan Asimetri Informasi dalam Hubungan Agensi. Lintasan Ekonomi. 19 (2), July 2002.

- ANUGRAH.(2019). CBC Ingatkan LDRBankSudah Tinggi, Perbankan Diminta Lakukan Ini [online], Harianterbit.com. https://www.harianterbit.com/ ekonomi/read/112901/CBC-Ingatkan-LDR-BankSudah-Tinggi-Perbankan-Diminta-Lakukan-Ini, [Date Accessed: 11/11/2019]

- BREAlEY, M. \& MARCUS. (2007). Dasar-dasar Manajemen Keuangan Perusahaan. Jakarta: Erlangga.

- BRIGHAM, E. F. \& HOUSTON, J. F. (2011). Dasardasar Manajemen Keuangan Terjemahan. Jakarta: Salemba Empat, Tenth edition.

- CHOI, F. D. S. \& MEEK, G. K. (2012). International Accounting. Jakarta: Salemba Empat. 
- HIDAYAH, N. (2014). The effect of company characteristics toward firm value in the property and real estate company in Indonesia stock exchange. International Journal of Business, Economics, and Law. 5(1), 1-8.

- HORNE, J. C. V. \& HOWICZ, J. M. W. J. R. (2012). Prinsip-Prinsip Manajemen. Jakarta. Thirteenth Edition.

- JENSEN, M. C. (1986). Agency Cost of Free cash Flow, Corporate Finance, and Takeovers. American Economic Review. 76(2), 323-329.

- JOGIYANTO, H. M. (2014). Teori Portofolio Dan Analisis Investasi. Yogyakarta: BPFE, Eighth Edition.

- KEOWN. A. J, et al. (2011). Manajemen Keuangan: Prinsip dan Penerapan Jakarta: PT. Indeks.

- LANG, M. H. \& LUNDHOLM, R. J. (1993). Cross-sectional determinants of analyst ratings of corporate disclosures Journal of Accounting Research. 246-271.

- LANG, M. H. \& LUNDHOLM, R. J. (1996). Corporate disclosure policy and analyst behavior, Accounting Review. 467-492.

- LUNDHOLM, R. J. \& MYERS, L. A. (2002). Bringing the future forward: The effect of disclosure on the returns-earnings relation. Journal of Accounting Research. 40(3), 809-839.

- $\quad$ MILGROM, P, R. (1981). Good news and bad news: Representation theorems and applications. The Bell Journal of Economics. 380-391.

- NURAINI, N. \& MUTTAQIN, A. (2018). Korelasi Antara Penerapan Akad Mudharabah dan Profitabilitas Pada Bank Syariah Mandiri. Falah: Jurnal Ekonomi Syariah. 3(1), 25-37.

- PRASETYONINGRUM, A. K. (2015). Analysis BI Rate and Return of Third Party Fund On Rate of Third Party Fund on Islamic Banking in Indonesia. In Conference In Business, Accounting, And Management (CBAM). 2(1), 104-116.

- PRASETYONINGRUM, A. K.(2015). Risiko Bank Syariah. Yogyakarta: Pustaka Pelajar. 46-49.

- RICHARD, M. (2019). Fintech Bakal Menggerus Pendapatan BankHinggaUS\$5 Miliar. Finansialbisnis. com. World Wide Web: https://finansial.bisnis. com/read/20191107/90/1168007/fintech-bakalmenggerus-pendapatan-bank-hingga-us5-miliar. [Data Accessed, 07/11/2019.]
- RIYANTO, B. (2010). Dasar-Dasar Pembelanjaan Perusahaan. Yogyakarta: BPFE, Fourth Edition.

- Samsul, M. (2006). Pasar Modal dan Manajemen Portofolio. Jakarta: Erlangga.

- SUDANA, I. M. (2013). Diversifikasi Investasi Saham: Perbandingan Risiko Total Portofolio Melalui Diversifikasi Domestik Dan Internasional. Jurnal Manajemen Teori dan Terapan|Journal of Theory and Applied Management. 6(1).

- TANDELILIN, E. (2010). Portofolio dan Investasi. Yogyakarta: Konisius.

- TASWAN. (2010). Manajemen Perbankan Konsep, Teknik, dan Aplikasi. Yogyakarta : UPP STIM YKPN.

- UTAMI, W. (2015). Financial performance and the quality of sustainability disclosure based on global reporting initiative: Value relevances study in Indonesia stock exchange, Mediterranean Journal of Social Sciences. 6(5 S5):243.

- UTAMI, W. \& WAHYUNI, P. D. (2018). ForwardLooking Information Based on Integrated Reporting Perspective: Value Relevance Study in Indonesia Stock Exchanges. Asian Journal of Economics, Business and Accounting. 8(4): 1-12.

- VERRECCHIA, R. E. (1983). Discretionary disclosure. Journal of aAccounting and Economics. 5(1): 179-194.

- WEYGANDT, KIMMEL, \& KIESO. (2014). Financial Accounting: IFRS Edition. Hoboken: John Wiley \& Sons, Inc. 